\title{
Architektura białostockich kościołów. Część IV. Przyszłość architektury - kierunki i drogi
}

\author{
Agnieszka Kłopotowska
}

Zakład Urbanistyki i Planowania Przestrzennego, Wydział Architektury, Politechnika Białostocka

\section{Maciej Kłopotowski}

Zespót Dydaktyczny Architektury Krajobrazu, Katedra Ochrony i Kształtowania Środowiska, Wydział Budownictwa i Inżynierii Środowiska, Politechnika Białostocka

\begin{abstract}
Streszczenie: W niniejszej publikacji podjęto próbę wskazania możliwych kierunków i dróg wyjścia z kryzysu, dotykającego współczesnej architektury kościołów rzymsko - katolickich w Polsce i Europie, w tym działania zmierzające do lepszej identyfikacji, wzmocnianie archetypu religijnego, przywracanie właściwej hierarchii, powrót do archetypu lokalnego, powrót do takich wartości jak: piękno, harmonia, synteza, podnoszenie świadomości i odpowiedzialności decydentów, poszukiwanie istoty Sacrum oraz tworzenie miejsca na Jego indywidualne i zbiorowe doświadczanie.
\end{abstract}

Słowa kluczowe: kościoły postmodernistyczne, kryzys architektury sakralnej, wartości architektury sakralnej

\section{Uwaga metodyczna}

Niniejsza publikacja stanowi część IV zbioru tekstów poświęconych tematyce kryzysu współczesnej architektury kościołów rzymsko - katolickich. Poruszana problematyka omówiona na przykładzie realizacji z obszaru Białegostoku, stanowi w istocie problem znacznie szerszy, dotykający obszaru kraju i Europy.

Część I - zawiera prezentację zrealizowanych i niezrealizowanych białostockich kościołów rzymsko - katolickich z lat 1617-1980

Część II - zawiera prezentację zrealizowanych i niezrealizowanych białostockich kościołów rzymsko - katolickich z lat 1980-2010

Część III - zawiera wynika analiz autorskich z zakresu problemów współczesnej architektury kościołów rzymsko - katolickich omówionych na przykładach konkretnych obiektów

Część IV - zawiera wyniki analiz autorskich stanowiących próbę wskazania możliwych kierunków i dróg pozwalających na naprawę obecnego stanu

Zamieszczone w końcowej części tekstu Podsumowanie, podobnie jak Wprowadzenie zawarte w Części I, odnoszą się do całości cyklu.

\section{Kontekst religijny}

\subsection{Identyfikacja}

Rozpoznawalność architektury świątyń katolickich od wieków stanowiła ważny manifest religijnej tożsamości. Architektoniczne eksperymenty końca ubiegłego wieku, które nie ominęły również Białegostoku, dowodzą bezsprzecznie, że odmienności tej nie wolno zatracić. Główna wytyczna formalna oraz sylweta bryły - elementy 
pierwszego kontaktu wzrokowego - powinny pozostać wyrazistym nośnikiem tradycji religijnej. Wymaga to ich świadomej kreacji jako sygnału - znaku przestrzennego, umożliwiającego łatwą identyfikację budowli jako kościoła katolickiego.

\subsection{Archetyp religijny}

Posoborowe zagubienie twórcze i podświadome powroty historyczne utwierdzają w przekonaniu, że powinnością projektantów budowli sakralnych jest sięganie do głębi własnych zasobów kulturowych i religijnych, czerpanie z własnej, ugruntowanej „biblioteki” środków wyrazu architektonicznego. Nie chodzi tu oczywiście o zatrzymanie czasu, utkwienie w przeszłości, beznamiętne powielanie sprawdzonych rozwiązań, ale o twórcze przetwarzanie, osadzenie w tradycji chrześcijańskiej i poszukiwanie w niej źródeł inspiracji. Być może należy nawet rozważyć możliwość powrotu do pewnych przedsoborowych rozwiązań (np. rzutu świątyń czy ich orientacji). Jedynie w oparciu o tradycyjne wartości możliwe będzie wypracowanie akceptowanego i „prawdziwego” wzorca współczesnej świątyni katolickiej.

\section{Kontekst czasoprzestrzenny}

\subsection{Hierarchia}

Podstawową zasadą projektową w zdefiniowanym kontekście jest ustalenie hierarchii ważności obiektów w strefie ich oddziaływania. W strukturze miasta świątynia od wieków stanowiła dominantę znaczeniową, a często również wysokościową. Nie znaczy to jednak, że powinna tym samym bezwzględnie i każdorazowo przyjmować gabaryty przestrzennej dominanty kubaturowej. Skala obiektu nie ma bezpośredniego przełożenia na jego pożądaną monumentalność. ${ }^{1}$ Doświadczenia przeskalowanych białostockich świątyń z lat 80 . i 90. wskazują na potrzebę powrotu do niewielkich, parafialnych kościołów o znaczeniu lokalnym. Tezę tę zdają się potwierdzać wyważone w skali kościoły wznoszone w Białymstoku w ostatnich latach.

\subsection{Archetyp lokalny}

Świątynia jako obiekt z założenia trwały, w przyszłości pretendujący do roli zabytku, nie musi bezwzględnie wpisywać się w krajobraz osiedla, w którym powstaje. Bardziej istotne niż dążenie do osiągnięcia spójności z najbliższym otoczeniem wydaje się poszukiwanie lokalnego archetypu- zrozumiałego, "oswojonego" języka twórczej narracji, osadzonej w architekturze rodzimego kręgu kulturowego, np. Podlasia. Wobec pewnego zagubienia twórców, wynikającego z braku stosownych kanonów u progu XXI w. poszukiwanie oparcia w architekturze lokalnej wydaje się szczególnie zasadne. Z całą pewnością nie mogą być to jednak bezkrytyczne cytaty z wybudowanych wcześniej kościołów, które stanowią skończone dzieła architektoniczne, ani też naśladownictwo niskich lotów architektury współczesnych zespołów mieszkaniowych.

\subsection{Aktualność}

Rozwój architektury jako sztuki wymaga nieustannej aktualizacji architektury sakralnej, która powinna każdorazowo odpowiadać duchowi epoki. Ucieczka w „bezpieczną stylistykę" architektury czasów minionych,

1 „Monument nie musi być zakrojony na wielką skalę, ale musi być poważny, godny, podniosły." Patrz: Wawrzyniak, W., Sacrum i monument, [w:] Budownictwo Sakralne i Monumentalne '2000, materiały: III Międzynarodowej Konferencji Naukowo - Technicznej, Politechnika Białostocka Białystok 2000. s. 412 
która w Białymstoku przybrała szczególną, karykaturalną formę jest historycznym fałszem. Należy poszukiwać współczesnych środków wyrazu oraz współczesnego pojęcia stosowności i adekwatności obiektu sakralnego. ${ }^{2}$

\section{Estetyka}

\subsection{Piękno}

Eksperymenty architektoniczne ubiegłego stulecia, których efektem stały się wzniesione w naszym mieście dziwaczne, przerysowane „postmodernistyczne" twory architektoniczne (zaś w skali kraju również surowe, zimne, bezimienne obiekty o "modernistycznych" konotacjach, czy w końcu przytłaczające przestrzenie powszechnie lansowanego "brutalizmu") - uczą respektu do bezkrytycznej pogoni za nowością. Dowodzą również dobitnie potrzeby powrotu do piękna jako wartości estetycznej. ${ }^{3}$ Wartości ponad stylem, modą, oryginalnością, pragnieniem zaszokowania odbiorcy czy indywidualnym manifestem twórczym.

\subsection{Harmonia}

Należy podjąć szczególne starania o uzyskanie harmonii pomiędzy zewnętrzną bryłą obiektu a architekturą i plastyką wnętrz. Podstawowe elementy wyposażenia powinny podkreślać charakter kościoła, współbrzmieć z jego wyrazem architektonicznym a jednocześnie nadawać szczególny, niepowtarzalny charakter świątyni. Staną się one bowiem rodzajem scenografii dla odprawianej liturgii. Muszą tym samym sprzyjać atmosferze modlitwy i kontemplacji. Atmosfery takiej z pewnością nie uda się osiągnąć kiczem i zlepkiem niespójnych elementów, znanych z większości białostockich (i wielu polskich) kościołów. Współczesny odbiorca oczekuje wnętrz o wysokich walorach estetycznych.

\subsection{Synteza}

Należy zwrócić szczególną uwagę na dbałość o estetyczną atrakcyjność i właściwą oprawę odprawianej liturgii. Liturgii, w której duchowość zostanie wsparta wysokim poziomem artystycznym muzyki instrumentalnej, śpiewu, gry światła, ale również elementami drugorzędnymi, np. barwą, dźwiękiem, zapachem. Percepcja wnętrza świątyń katolickich tradycyjnie opiera się bowiem na polisensorycznym odbiorze przestrzeni świątyni.

Poszczególne elementy decydujące o klimacie wnętrza wymagają szczególnej uwagi projektowej, tak pod względem estetycznym jak i specjalistycznym, np. odpowiednia akustyka wnętrz, właściwe rozplanowanie strefy chóru, zaprojektowanie przestrzeni dla konkretnych, wybranych do kościoła instrumentów muzycznych. Atrakcyjna obrzędowość osadzona w tradycji Kościoła może stać się elementem przyciągającym rzesze parafian. Wyraża również szacunek dla wiernych, którzy czują się adresatami i uczestnikami wydarzeń kulturalnych Kościoła.

\section{Edukacja}

\section{1. Świadomość}

Kościół powinien powrócić do swojej roli edukatora w zakresie tożsamości kultury katolickiej. Niezbędne wydaje się tutaj nieustanne eksponowanie ciągłości kulturowej jako podstawowego bogactwa religii. Szczególnie

2 "Tak więc poszukiwanie choćby najpiękniejszych i najoryginalniejszych brył i najfunkcjonalniejszych i najbardziej nastrojowych wnętrz, nic nam przynieść nie może, dopóki nie zdobędziemy się na nadanie wnętrzom sakralnym sensu metafizycznego i estetycznego na miarę takiej metafizyki i takiej estetyki, jakiej wymagają nie epoki minione, lecz nasza, inaczej trudna, współczesność." Patrz: Gutowski, M., Przestrzeń kościoła, jej historyczne przemiany i wspótczesna wymowa, [w:] Budownictwo Sakralne '98, materiały: Il Konferencji Naukowo - Technicznej Budownictwo Miast i Wsi, Politechnika Białostocka, Białystok 1998, s. 132.

3 Patrz: Natalia Budzyńska, Betonowe Jeruzalem, [w:] Przewodnik katolicki 48/2009. 
ważne zdaje się również przypominanie znaczenia tradycyjnej symboliki religijnej. ${ }^{4}$ Znajomość reguł jej stosowania i właściwego odczytu jest warunkiem wymiany myśli pomiędzy projektantem a odbiorcą dzieła sakralnego.

Kościół w naturalny sposób staje się również muzeum własnej religii. Winien zatem udostępniać wiernym dzieła sztuki, pamiątki, fotografie... przypominające o dorobku minionych pokoleń, ale również o ważnych wydarzeniach z życia parafii czy diecezji. Lokalne sale muzealne czy galerie zorganizowane np. w dawnych salach dydaktycznych ${ }^{5}$ niewątpliwie wzmocnią w wiernych poczucie uczestnictwa we wspólnocie, która posiada własne korzenie.

\subsection{Odpowiedzialność}

Niewiedza, trudności ekonomiczne, pośpiech - nie mogą być usprawiedliwieniem bylejakości, powierzchowności, bagatelizowania problemu estetyki kościołów, sprowadzenia obiektu sakralnego do roli hali mającej pomieścić określoną liczbę parafian. Zadaniem mecenasa i inwestora jest dbałość o wysoki poziom merytoryczny i estetyczny świątyni. Odpowiedzialność zaczyna się z chwilą wyboru właściwego, wyedukowanego projektanta, świadomego zasobów kulturowych Kościoła oraz warunków czasoprzestrzennych, w których tworzy. Wybór najlepszego rozwiązania w dużej mierze zależy od umiejętności porozumienia pomiędzy architektem a zleceniodawcą, który również musi mieć odpowiednie przygotowanie do powierzonej mu roli. Niezbędne wydaje się również zlecenie wykonania oddzielnego projektu wnętrz równolegle z projektem architektonicznym. Opracowanie to powinno zostać sporządzone przez wykwalifikowanych projektantów, działających w porozumieniu z głównych architektem kościoła oraz specjalistami w zakresie akustyki i oświetlenia. Równie ważny jest nadzór techniczny nad wykonawcą prac budowlanych, gwarantujący zgodność z projektem technicznym, wybór właściwych materiałów budowlanych i wykończeniowych a nade wszystko wysoki poziom wykonawczy.

\section{Sacrum}

\subsection{Istota}

Najważniejszym, niezwykle trudnym wyzwaniem projektantów współczesnych świątyń katolickich jest uchwycenie (i odzwierciedlenie w architekturze) aktualnego sensu pojęcia sacrum. Sacrum na miarę czasu i miejsca- na miarę tu i teraz. Powrót do istoty Rzeczy wydaje się możliwy nie na zasadzie lansowania konkretnej doktryny stylistycznej, ${ }^{6}$ lecz poszukiwania (nieustannie na nowo) środków dla wyrażenia najgłębszej Wartości. Wartości ponadhistorycznej i ponadstylistycznej, którą w architekturze od wieków egzemplifikują niezmienne doznania estetyczne: wrażenie tajemniczości, niezwykłości, odświętności, podniosłości, nieosiągalności, stopniowego wyciszenia, wyniesienia, warstwowości sakrum ${ }^{7}$. Styl architektoniczny nie może zatem być celem samym w sobie, ale jedynie środkiem, umożliwiającym projektantowi i odbiorcy dzieła zbliżenie się do fenomenu sacrum, również poprzez przeżycie estetyczne. ${ }^{8}$ względu na rozłączność edukacji religijnej i oświaty powszechnej. Fakt ten miał przełożenie na bryłę i kompozycję obiektu. Od szeregu lat nauka religii prowadzona jest na terenie szkół. Dawne sale katechetyczne spełniają dziś inne funkcje.

6 „Kościół żadnego stylu nie uważa za swój własny.” Patrz: Nadrowski, H., Sacrum przestrzeni kościelnych, Jedność, Kielce 2005.

7 Alexander, Ch., Język wzorców. Miasta, budynki, konstrukcja, tłumaczenie: A. Kaczanowska, K. Maliszewska, M. Trzebiatowska, Gdańskie Wydawnictwo Psychologiczne, Gdańsk 2008, s. 339

8 „Przychodzi więc w koniec zapytać. Czy i kiedy pojawią się znów tak wielkie siły duchowe by, jak w średniowieczu, wytworzyć jednorodną ideę przestrzennego kształtu sakralnej budowli, wyrażającej myśl metafizyczna ważną i nośną w naszym czasie?" Patrz: Gutowski, M., Wpływ treści ideowych na kształt architektury sakralnej, [w:] Budownictwo Sakralne `96, materiały: Konferencji Naukowo - Technicznej Budownictwo Miast i Wsi, Politechnika Białostocka, Białystok 1996, s. 49. 


\subsection{Miejsce}

Podstawę żywego Kościoła od zarania dziejów stanowią wspólnota i indywidualność. Niezwykle ważne wydaje się odzwierciedlenie tej dychotomii w architekturze. Świątynia powinna być zatem miejscem umożliwiającym realizację obu tych form uczestnictwa w życiu Kościoła. W zależności od potrzeb i indywidualnych preferencji wierni powinni na powrót znaleźć w przestrzeni świątyni możliwość uczestnictwa w zbiorowych nabożeństwach czy rozważaniach oraz element wycofania, ciszy, samotnej modlitwy, kontemplacjị . Niezwykle ważne jest również zaprojektowanie strefy spowiedzi w sposób zapewniający intymność tego sakramentu ${ }^{10}$.

\section{Podsumowanie}

Miasto, jako nieustannie ewoluujący żywy obraz historii cywilizacji, staje się wielokrotnie naturalnym muzeum architektury sakralnej. Szacunek i podziw dla świątyń oraz ich twórców od wieków sprawiał, że w tkance miasta stopniowo nawarstwiały się dokonania kolejnych pokoleń. Sąsiadujące ze sobą obiekty historyczne różnych epok układają się dzisiaj w historię Kościoła, umożliwiając płynną podróż w czasie, rejestrację przemian światopoglądowych i dokonań twórczych zapisanych w architekturze. Analizując przemiany budowli sakralnych krok po kroku od romanizmu do modernizmu, zauważamy niezmienną potrzebę ciągłości kulturowej. Każdy kolejny styl czerpie z języka przeszłości, ale również wnosi do tego języka własne, nowe wartości.

Naturalną ewolucję artefaktów wydaje się jednak przerywać postmodernizm. Być może brakuje nam jeszcze odpowiedniego dystansu, aby obiektywnie, bez emocji uczestników zdarzeń oceniać współczesne nam zjawiska. Jednak już z tej nieodległej perspektywy czasowej, wydaje się że czas postmodernizmu dla architektury kościołów katolickich naszego miasta nie był jedynie przejściowym etapem w toczącym się naturalnym rytmem kole historii. Stał się rodzajem wstrząsu, punktem zwrotnym, po którym, być może, nic już nie będzie jak dawniej. Jedynie w teorii posuwamy się do przodu- powstają kolejne kościoły, wpisujące się w zauważalne nurty bądź pojedyncze eksperymenty twórcze. Trudno jednak oprzeć się wrażeniu, że nasz system wartości rozsypał się, jak się wydaje bezpowrotnie. Tworzymy w świecie, w którym artysta nade wszystko ceni sobie wolność twórczą. W rzeczywistości pozbawionej jasnych reguł i klarownych kanonów wolność może łatwo zamienić się w pułapkę - wygodne wytłumaczenie dla niewiedzy, braku talentu czy rzetelnej znajomości warsztatu.

W tej sytuacji wypracowanie właściwych środków wyrazu estetycznego, odpowiadających potrzebom współczesnego Kościoła, wydaje się zadaniem wyjątkowo trudnym i wyjątkowo delikatnym. Zaprezentowane postulaty z pewnością nie przyniosą natychmiastowego rozwiązania kryzysu współczesnej architektury sakralnej w skali Białegostoku czy tym bardziej Polski. Są raczej autorskim wołaniem o zauważenie problemu i o poszukiwanie jego rozwiązania - nie w pogoni za nowością ani też nie w bezkrytycznym naśladownictwie historii, ale - poprzez powrót do istoty własnej tradycji. Tradycji rozumianej nie jako tkwienie w przeszłości, ograniczenie twórczych poszukiwań, wyhamowanie naturalnego postępu, lecz jako duchowy fundament i żywą pamięć Kościoła, skarbiec jego kultury religijnej, a nade wszystko jako oparcie - ponadczasowy, niezmienny system wartości, odpowiadający niezmienności istoty wiary. „Świątynia musi być tradycyjna. ${ }^{.11}$ Pielęgnowana powtarzalność form i znaczeń to duchowe dziedzictwo każdej religii.

\section{Literatura}

[1] Alexander, Ch., Język wzorców. Miasta, budynki, konstrukcja, tłumaczenie: A. Kaczanowska, K. Maliszewska, M. Trzebiatowska, Gdańskie Wydawnictwo Psychologiczne, Gdańsk 2008.

[2] Budzyńska, N., Betonowe Jeruzalem, [w:] Przewodnik Katolicki 48/2009.

9 Patrz: Twarowski, M., Metoda Projektowania kościoła, Wydawnictwa Rady Prymasowskiej Budowy Kościołów Warszawy (Praca na prawach rękopisu), Warszawa 1985, s. 7, s. 39.

10 Patrz: Twarowski, M., Metoda Projektowania kościoła, Wydawnictwa Rady Prymasowskiej Budowy Kościołów Warszawy (Praca na prawach rękopisu), Warszawa 1985, s. 58.

11 Problematykę tę szeroko prezentuje Jerzy Uścinowicz. Patrz: Uścinowicz, J., Symbol. Archetyp. Struktura. Hermeneutyka tradycji w architekturze świątyni ortodoksyjnej, Politechnika Białostocka, Białystok 1997, s. 5. 
[3] Cirlot, J. E., Stownik symboli, tłumaczenie: I. Kania, Znak, Kraków 2006.

[4] Gutowski, M., Przestrzeń kościoła, jej historyczne przemiany i wspótczesna wymowa, [w:] Budownictwo Sakralne `98, materiały: II Konferencji Naukowo-Technicznej Budownictwo Miast i Wsi, Politechnika Białostocka, Białystok 1998.

[5] Gutowski, M., Wpływ treści ideowych na kształt architektury sakralnej, [w:] Budownictwo Sakralne '96, materiały: Konferencji Naukowo-Technicznej Budownictwo Miast i Wsi, Politechnika Białostocka, Białystok 1996.

[6] Kościoły Białegostoku, praca zbiorowa pod redakcją: A. Kubasika, Pomorska Oficyna Wydawniczo-Reklamowa, Bydgoszcz 2008.

[7] Kucza-Kuczyński, K., Między wzniosłościa a pokora - pytania o współczesna przestrzeń sakralna w Polsce „, [w:] Budownictwo Sakralne '96, materiały: Konferencji Naukowo-Technicznej Budownictwo Miast i Wsi, Politechnika Białostocka, Białystok 1996.

[8] Kucza-Kuczyński, K., Przez liturgię - do architektury: kościoły świata na przełomie wieków, [w:] Budownictwo Sakralne i Monumentalne '2002, materiały: IV Międzynarodowej Konferencji Naukowo-Technicznej, Politechnika Białostocka, Białystok 2002.

[9] Nadrowski, H., Integralny i konserwatywny program podstawa projektowania kościołów, [w:] Budownictwo Sakralne i Monumentalne `2004, materiały: V Międzynarodowej Konferencji Naukowo-Technicznej, Politechnika Białostocka, Białystok 2004.

[10] Nadrowski, H., Kościoły naszych czasów. Dziedzictwo perspektywy, WAM, Kraków 2000.

[11] Nadrowski, H., Sacrum przestrzeni kościelnych, Jedność, Kielce 2005.

[12] Nowe Kościoły w Polsce, tekst: K. Kucza-Kuczyński, Instytut Wydawniczy PAX, Warszawa 1991.

[13] Pawlicki, B. M., Sacrum - wrażliwość twórcza artysty, [w:] Architektura sakralna w kształtowaniu tożsamości kulturowej miejsca, praca zbiorowa pod redakcją: E. Przesmyckiej, Wydawnictwo Politechniki Lubelskiej, Lublin 2006.

[14] Polska architektura sakralna XX wieku, katalog wystawy, Muzeum Architektury we Wrocławiu, Wrocław 1997.

[15] Twarowski, M., Metoda Projektowania kościoła, Wydawnictwa Rady Prymasowskiej Budowy Kościołów Warszawy (Praca na prawach rękopisu), Warszawa 1985.

[16] Uścinowicz, J., Symbol. Archetyp. Struktura. Hermeneutyka tradycji w architekturze świątyni ortodoksyjnej, Politechnika Białostocka, Białystok 1997.

[17] Wawrzyniak, W., Sacrum i monument, [w:] Budownictwo Sakralne i Monumentalne `2000, materiały: III Międzynarodowej Konferencji Naukowo-Technicznej, Politechnika Białostocka, Białystok 2000.

[18] Wawrzyniak, W., Sacrum w architekturze. Paradygmaty kościoła św. Ducha i Zboru Zielonoświatkowego we Wrocławiu, Oficyna Wydawnicza Politechniki Wrocławskiej, Wrocław 1996.

\title{
Architecture of Białystok churches. Part IV. Future of architecture - directions and roads
}

\begin{abstract}
In this publication an attempt to show the possible directions and means of getting out of the crisis, touching the contemporary architecture of Roman Catholic churches in Poland and for Europe was made, including activity aimed at the better identification, strengthening of religious archetype, restoring the appropriate hierarchy, return to the local archetype, return to such values as: beauty, harmony, synthesis, raising the awareness and the responsibility of decision-makers, seeking the being the Sacred and creating the space for It's individual and collective experiencing.
\end{abstract}

Keywords: postmodernist churches, crisis of sacred architecture, values of sacred architecture 